\title{
IPad Acceptance by English Learners in Saudi Arabia
}

\author{
Barry A. M. Lawrence ${ }^{1}$ \\ ${ }^{1}$ Saudi Electric Services Polytechnic, Dammam, Kingdom of Saudi Arabia \\ Correspondence: Barry A. M. Lawrence, Saudi Electric Services Polytechnic, P. O. Box 313, Qatif 31911, \\ Eastern Province, Kingdom of Saudi Arabia. Tel: 0096-59-658-2880. E-mail: b_lawrence@sesp.edu.sa
}

Received: October 7, 2016 Accepted: November 6, 2016 Online Published: November 7, 2016

doi: 10.5539/elt.v9n12p34 URL: http://dx.doi.org/10.5539/elt.v9n12p34

\begin{abstract}
This study used the Unified Theory of Acceptance and Use of Technology (UTAUT; Venkatesh, Morris, Davis, \& Davis, 2003) model to investigate factors predicting the acceptance of iPad tablets by learners of English as a foreign language (EFL) at a technical vocational college in Saudi Arabia. An online survey was conducted on 199 male learners, and a simultaneous multiple regression analysis was conducted on the data. The results indicated that a belief in the device's educational potential, a sense that it was straightforward to use, and the perception that the infrastructure would support usage were all significant predictors of the behavioral intention to use iPads. Social factors did not indicate an acceptance of the device. The findings highlighted areas of importance for educators intending to adopt mobile devices in second language instruction and partially supported the application of the UTAUT.
\end{abstract}

Keywords: IPad, mobile-assisted language learning, mobile learning, Saudi Arabia, Unified Theory of Acceptance and Use of Technology, UTAUT

\section{Introduction}

Today, the most widely used mobile learning device in the classroom is the Apple iPad (Gasperini \& Culen, 2011; Murray \& Olcese, 2011). Equipping educators and learners with the requisite skills to cope with educational technology such as this is becoming essential as e-learning becomes more established in the Kingdom of Saudi Arabia (KSA; Al-Asmari, \& Khan, 2014). This increasing emphasis on technology represents a vital element of current educational reform intended to develop a more highly skilled workforce capable of reducing dependence on expatriate workers. A related, increasingly important, and rapidly developing area of expansion in higher education is technical and vocational training. Indeed, Al-Khotani (2014) stated that the 100,000 students receiving vocational education in 2014 are projected to reach 450,000 by 2020 . A key component of this training is typically general English and ESP. However, prior schooling instruction in EFL throughout the KSA has been criticised for resulting in low levels of English proficiency among school graduates (Alrashidi \& Phan, 2015; Rajab, 2013) due to a largely teacher-centered approach couched in grammar translation and rote learning (Alrabai, 2016). Crucially, the Saudi Ministry of Education has earmarked educational technology as a solution to this problem (Alresheed, Leask, \& Raiker, 2015). Yet this reform comes at a cost. In 2013, for example, 55 billion USD were spent, amounting to $10 \%$ of the country's GDP (Dhir \& Al-khatani, 2013). It is problematic that despite such considerable investment, the prevalence of the iPad, and the burgeoning expansion of technical and vocational training in the KSA, little research exists that investigates how best to leverage the potential of the iPad as a language-learning tool in this educational context.

Crucial to the effective integration of the iPad in education is achieving acceptance of the device by learners, and this may hinge on successfully addressing two issues. Although mobile learning (m-learning) and mobile-assisted language learning (MALL) are becoming particularly prevalent in education, due to increased ownership, falling costs, and advancing capabilities (Stockwell, 2013), experience suggests that simply distributing technology in an educational setting does not automatically improve performance. Indeed, technology has often been underemployed and underutilized for instructional purposes (Gray, Thomas, \& Lewis, 2010). To optimize learning, educators must firstly harness the purported strengths of these devices. Portability is key, leading to increased flexibility, choice, and personalization. These factors support greater autonomy, enriched collaboration among learners, and access to more situated learning contexts (Abu-Al-Aish \& Love, 2013). Secondly, maximizing the potential benefits involves overcoming the potential obstacles. Ertmer $(1999,2005)$ lists a number of potential barriers to integration from an educator's perspective, dividing them into first-order and second-order barriers. 
First-order barriers are environmental, including inadequate hardware, software access, training, and administrative and technical support. Second-order barriers are internal, encompassing levels of confidence and beliefs about the educational potential of the devices. Given that implementing m-learning from the orientation of learner experience is necessary (Kearney, Schuck, Burden, \& Aubusson, 2012), it is notable that many of these potential barriers, when poorly handled, also represent barriers from a learner's perspective. A lack of technical support and training would discourage both the instructor and learner, for example. Thus, educators and policymakers must identify, understand, and minimize these potential barriers while simultaneously adhering to the strengths of the device. Such an approach should support greater acceptance. This can then lead to a learning context characterized by higher engagement and thus more sustained learning. However, despite these potential benefits, little research has addressed factors predicting the acceptance of the iPad as a language-learning tool in the KSA.

Of great potential benefit in deepening understanding of iPad acceptance in Saudi Arabia is the Unified Theory of Acceptance and Use of Technology (UTAUT; Venkatesh et al., 2003), currently the most prominent framework that explains acceptance among users. Its strength lies in its inclusive approach, synthesizing and unifying the key elements of earlier models: the Theory of Reasoned Action (TRA; Fishbein, \& Ajzen, 1975), the Technology Acceptance Model (Davis, 1989), the Motivational Model (Davis, Bagozzi, \& Warshaw, 1992), the Extended Technology Acceptance Model (Venkatesh \& Davis, 2000), the Theory of Planned Behaviour (TPB; Ajzen, 1991), the Model of PC Utilization (Thompson, Higgins, \& Howell, 1991), Innovation Diffusion Theory (Rogers, 1995), the Combined Technology Acceptance Model and Theory of Planned Behaviour (Taylor \& Todd, 1995) and Social Cognitive Theory (Bandura, 1986). See Figure 1.

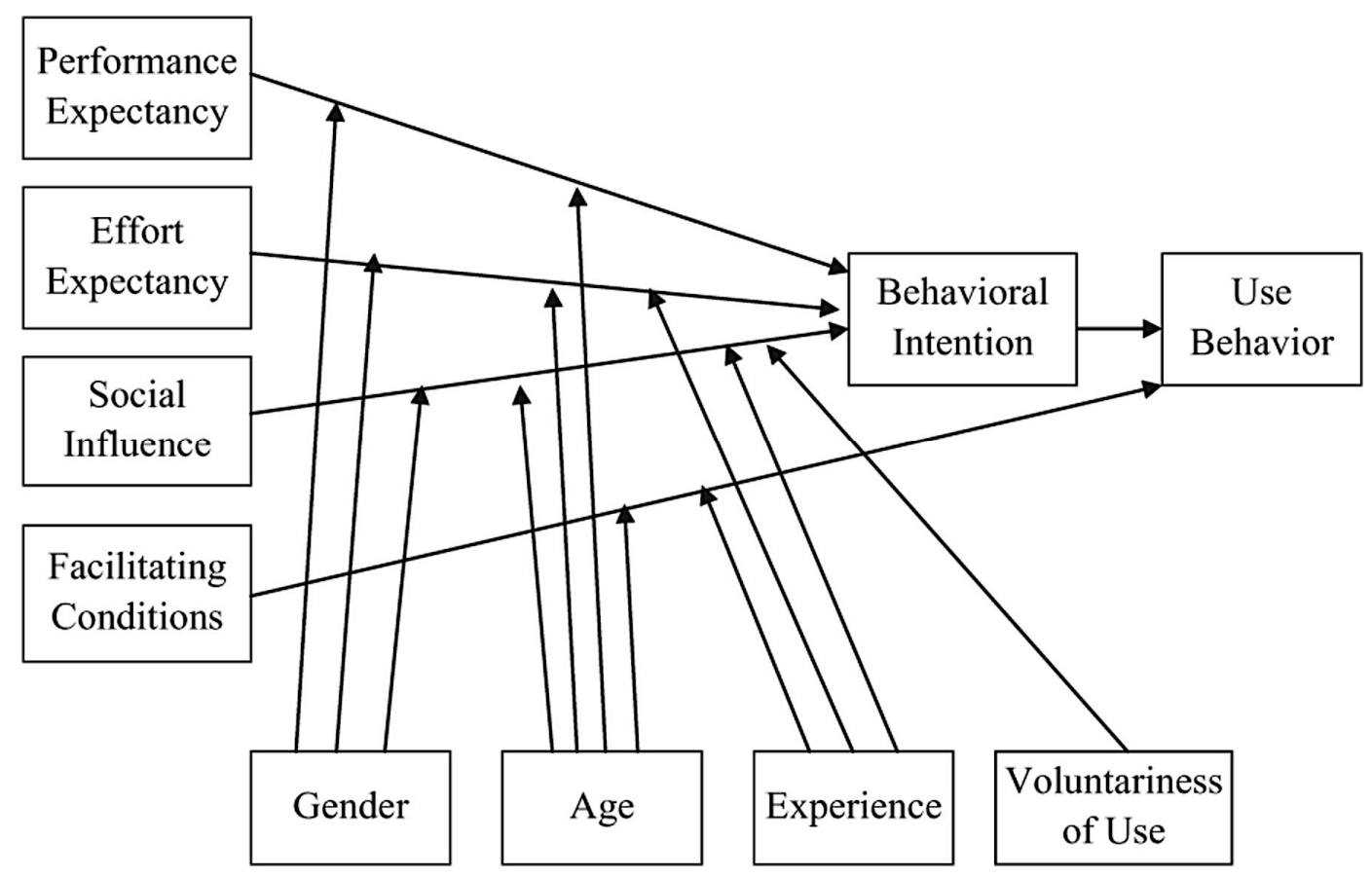

Figure 1. Unified Theory of Acceptance \& Use of Technology (Venkatesh et al., 2003)

The UTAUT posits two endogenous variables, behavioral intention to use and use behavior, as measures of technology acceptance. Behavioral intention captures the extent to which a user intends to, and is willing to, use a technology. Four exogenous variables predict behavioral intention and use behavior: performance expectancy, the degree to which learners believe the technology will improve performance; effort expectancy, the degree to which users feel the technology is easy to use; social factors, the degree to which users think that important others believe they should use the technology; and facilitating conditions, such as organizational and technical infrastructure. Gender, age, education, and voluntariness of use represent moderating variables, mediating the effect of the main predictors. The UTAUT model has been demonstrated to capture up to $70 \%$ of the variation in the behavioral intention to use a technology (Venkatesh et al., 2003). However, despite its relative prominence, 
few studies of iPad acceptance have adopted this model in educational settings in the KSA.

The factors governing learner acceptance of iPads in the KSA are not fully understood despite the levels of interest, investment in e-learning, and considerable complexities of integration. Thus, to inform educators and policymakers aiming to implement these devices, I explored the factors critical in supporting learner acceptance. Specifically, this paper uses the UTAUT model of technology acceptance to identify the factors most salient in a learner's decision to adopt and use iPad technology in learning EFL at a technical vocational training college in the KSA. A secondary aim is to validate the use of the model in this context.

\subsection{The UTAUT Model}

The UTAUT model has been applied across a range of contexts. For example, of 20 studies reviewed, Attuquayefio and Addo (2014) found 12 focused on education, whereas four addressed telecommunications, five investigated banking, and five queried health. Although many studies have validated the UTAUT model as predictive of user acceptance in an educational setting, results have sometimes conflicted. For instance, Maldonado, Khan, Moon, and Rho (2011) surveyed student acceptance of e-learning in a secondary school in Peru. Their findings supported the UTAUT, with social factors found to be a strong predictor. Deng, Liu, and Qi (2011) used the model to investigate the determinants of the adoption of a web-based question-and-answer service. The results largely supported the UTAUT, although here social factors were not a significant predictor of acceptance. Sumak, Polancic, and Hericko (2010) found performance expectancy and effort expectancy to be non-significant predictors of the behavioral intention to use Moodle, while Maldonado et al. (2011) did not find facilitating conditions to be a significant predictor of the intention to adopt e-learning. Indeed, Taiwo and Downe (2013) conducted a meta-analysis on the UTAUT model over 37 empirical studies. The findings indicated that only the relationship between performance expectancy and behavioral intention was strong, whereas the relationships between behavioral intention and both effort expectancy and social influence were weaker. The association between facilitating conditions and use behavior was also weak. Based on these inconsistencies in results obtained in educational settings, there is clear need to investigate the utility of the UTAUT in assessing iPad acceptance in a vocational EFL context in the KSA.

\subsection{UTAUT and iPads}

Despite a general lack of studies implementing the UTAUT to predict acceptance of iPads, some literature does exist. Magsamen-Conrad, Upadhyay and Dowd (2015) used the framework to calculate acceptance of the device across age groups in the US. The results from a survey of 899 respondents were subject to bivariate correlational, MANCOVA, and stepwise regression analysis; they suggested generational differences between the relative influences of predictors. Controlling for age, gender, and use behavior, only effort expectancy and facilitating conditions were significant predictors of iPad acceptance, accounting for $24 \%$ of the variance. Although supportive of the UTAUT as a predictor of iPad acceptance, the North American context and focus on age hindered generalization to the immediate context, where observed ages fall into a narrow range. In a related study, the UTAUT was used to assess iPad acceptance in education (Boubert, Clements, Delaitre, Purdue, \& Lewis, 2015). The researchers surveyed 246 students across the faculty of science and technology at Westminster University, following an initial rollout of iPads. Through structural equation modelling, the results indicated that performance expectancy and facilitating conditions predicted the behavioral intention to use iPads. Although results both highlight factors impacting on iPad acceptance and partial validate the UTAUT in relation to iPads specifically, the differing cultural context and contrasting subject areas once again hamper attempts to generalize the findings to the current study.

\subsection{UTAUT and the KSA}

A potentially problematic factor is the lack of studies implementing the UTAUT in educational settings in the cultural context of the KSA. Observing that models must be robust across cultures, and that most studies incorporating the UTAUT have been conducted in North American settings, Al-Gahtani, Hubona and Wang (2007) used the model to investigate user acceptance of ICT in the KSA. Drawing on Hofestedes' (1980) cultural dimensions to rationalize differences in findings compared with western studies, the researchers surveyed 77 knowledge workers regarding their technology acceptance of a range of ICT devices. Of note, the system-specific predictor of social factors was replaced with a non-system-specific, similar construct of social norm, taken from the preceding TRA and TPB models. Results showed that, while performance expectancy and social norm predicted behavioral intention, effort expectancy and facilitating conditions did not. This study is important as it provides support and partial validation for the UTAUT in the KSA. However, numerous differences still arise, compared to the current paper. The mixed-gender, multi-device design, the element of choice inherent in user behaviour, and the non-educational context interfere with an extrapolation of findings in relation to the context of 
this study, highlighting the need for further studies utilizing the UTAUT in this particular educational and cultural setting.

Although few studies have implemented the UTAUT to address m-learning in Saudi Arabia, Nassuora (2013) used a modified model, incorporating attitude as a predictor, to assess acceptance of m-learning at Al-Faisal University. A survey was conducted on 80 participants of mixed gender, and the results were analysed via bivariate correlation analysis. The findings indicated that both performance expectancy and effort expectancy correlated positively with behavioral intention, while social factors and facilitating conditions correlated positively with attitude, which, in turn, correlated positively with behavioral intention. This study is significant in that it furthers understanding of acceptance of mobile learning in a socio-educational context close to that of the current paper. It is also encouraging that the results partially support the UTAUT as a predictor of m-learning acceptance in the KSA. Yet many differences exist between Nassuora's study and the current paper. Firstly, Nassuora's study used a qualitatively different, modified UTAUT. Second, adopting m-learning appears to have been voluntary. Also, the study seems to have been carried out prior to any form of implementation, whereas in the current study data is collected following integration. The mixed gender sample and the potentially differing profile of learners at a university versus a technical college further preclude generalizations. Lastly, the use of bivariate correlation, while understandable given the relatively small sample size, fails to capture variance caused by inter-related predictors. Thus, it is clear that further exploration of the iPad acceptance in the KSA is warranted.

In order to resolve inconsistencies in prior studies, further understanding of the acceptance of MALL, and support policymakers and educators concerned with integration of mobile devices, this study will investigate factors affecting acceptance of iPads in EFL in the KSA. In doing so, a secondary aim is to validate the UTAUT model in this context. Although there are studies concerning technology acceptance in the Gulf, few are specific to MALL in the Saudi Arabian context. More specifically, few concern iPad integration in EFL programmes in vocational education, despite the sharply growing importance of this sector and the costs involved in the one-to-one deployment of tablets. Therefore, this study will adopt the prominent UTAUT model to investigate acceptance of iPads as tools for learning EFL in a tertiary, vocational context. In keeping with the premises of the model, the study will evaluate the role of performance expectancy, effort expectancy, social factors, and facilitating conditions in predicting the behavioral intention to use iPads. Consequently, the following hypotheses will be tested:

H1 - Performance expectancy will have a positive influence on the behavioral intention to use iPads.

H2 - Effort expectancy will have a positive influence on the behavioral intention to use iPads.

H3 - Social factors will have a positive influence on the behavioral intention to use iPads.

H4 - Facilitating conditions will have a positive influence on the behavioral intention to use iPads.

\section{Method}

\subsection{Research Method}

This quantitative study adopted a non-experimental, correlational research design with a convenience sample of one group, comprising learners in a foundation year program. To investigate the four hypotheses, a quantitative survey was administered to evaluate the degree to which the four exogenous variables of the UTAUT model predict the behavioral intention to use iPads.

\subsection{Participants and Course}

The study was conducted at Saudi Electric Services Polytechnic (SESP), where the 220 learners enrolled in a foundation year program at the time of the data collection were using iPads. The devices had been distributed via one-to-one deployment. Users took permanent possession of the tablets, allowing for uninterrupted access. This supports autonomy, personalization, and choice, allowing situated learning and encouraging collaboration. The lessons are delivered via the iTunes U learning management system. Through this platform, interactive content, such as in-house, technical ESP iBooks and instructional media, are distributed. Assignments incorporating the principles of challenge-based (Johnson, Smith, Smythe, \& Varon, 2009) and project-based learning are similarly distributed. Work is completed using apps downloaded onto devices before being submitted via iTunes $U$, which is also used as a forum for private and group feedback and discussion. Learners receive 24 hours of English lessons each week, over three thirteen-week trimesters. Instructors who speak English as L1 deliver the lessons in English, and the classes, ranging from 12 to 18 learners, are grouped by proficiency, based on the initial placement tests taken upon orientation.

A total of 199 learners participated in the survey. All were male students of a similar age $(M=21.5)$. The respondents used iPads while studying a foundation year course, comprised of general English and technical ESP. 
All were Saudi Arabian, and most had studied English for 5 years in intermediate and secondary school prior to enrolling in the polytechnic. A small number $(n=5)$ had lived in a country where English was spoken as L1 over a period of $1-5$ years. A small number $(n=7)$ had received EFL instruction at other technical vocational colleges prior to transferring to SESP.

\subsection{Instrument and Measures}

To empirically address the hypotheses, the UTAUT model was amended, which often occurs (Al-Qeisi, Dennis, Hegazy, \& Abbad, 2015). Use behavior was excluded from the model, since a large proportion of use behavior was dictated by organizational policy and scheduling. Indeed, Blackwell, Lauricella, Wartella, Robb, \& Schomburg (2013) stated that measures of integration based on frequency and duration of use might not be valid indicators for this reason. Thus, the behavioral intention to use iPads was considered the sole outcome measure; this approach has precedence in the KSA (Nassuora, 2013). Behavioral intention was taken as a measure of optimal use: rather than simply meeting minimum expectations, this construct represents the extent to which learners are willing to optimize usage in order to enhance learning. A survey (see the Appendix) was developed to assess the factors affecting iPad acceptance, using five-point Likert scale items, ranging from $1=$ strongly disagree to $5=$ strongly agree. Individual scale items were averaged to provide indices. The independent (predictor) variables were performance expectancy (PE), effort expectancy (EE), social factors (SF), and facilitating conditions (FC). The dependent (criterion) variable was behavioral intention to use the iPad (IU). Prior studies served as the basis for individual scale items, which were primarily based on the work of Venkatesh et al. (2003) and validated in a Saudi Arabian context (Al-Gahtani et al., 2007). The survey consisted of 19 Likert items, with 3-4 items per variable. Based on piloting feedback, modifications were made to the survey to better measure acceptance of a mobile device. Thus, an item measuring performance expectancy, such as I find computers useful in my job (Al-Gahtani et al., 2007) was adapted to address self-directed learning and extended into two items: I find the iPad useful in my study at work and I find the iPad useful in my study at home.

\subsection{Procedure}

The survey was converted into Arabic and translated by two IT and EFL experts, who were both speakers of Arabic as L1 and advanced speakers of English, and final meanings were converged upon. The survey was then piloted on one class prior to the data collection $(n=18)$, and feedback was solicited. Internal reliability was measured, with Cronbach's alpha values within acceptable ranges $(M=.89)$. The survey was presented alongside language background questions, and it was delivered to and submitted by respondents online via Google Forms in April 2015. Survey instructions emphasized the confidential nature of participation. Items were presented simultaneously in L1 and L2 to aid comprehension and subsequent analysis. At the time of the data collection, learners had been using iPads for 5 months. Data were collected over a period of one week, and response rate was high (90\%). Data was cleaned and exported as a .CSV file to IBM's Statistical package for the Social Sciences (SPSS), Version 23. Following checks for outliers and normal distribution, simultaneous multiple regression was applied to investigate the predictors of the behavioral intention to use iPads as an EFL learning tool. Performance expectancy, effort expectancy, social factors, and facilitating conditions were submitted for analysis to find the most appropriate regression model.

\section{Results}

Data was obtained for 198 learners. The descriptive data are presented in Table 1.

Table 1. Descriptive statistics for predictors and output measures

\begin{tabular}{llllll}
\hline Measure & $M$ & $S D$ & Skew & Kurtosis & $\alpha$ \\
\hline PE & 3.83 & 1.26 & -1.022 & -.135 & .93 \\
EE & 4.02 & 1.20 & -1.203 & .290 & .94 \\
SF & 3.87 & 1.06 & -.891 & .230 & .85 \\
FC & 3.98 & 1.08 & -1.202 & .765 & .88 \\
IU & 3.99 & 1.21 & -1.098 & .122 & .93 \\
\hline
\end{tabular}

The dataset was checked for outliers. None were present. Although the data were skewed negatively, the values were within acceptable ranges (George \& Mallery, 2010). Thus, assumptions of normality appear to have been upheld. The data were subject to reliability and validity testing to ensure that the results were both consistent and 
free from error. Cronbach's alpha coefficient $(\alpha)$ was used to assess the reliability of the data collection instrument. The values obtained fell within the acceptable guidelines, and the mean Cronbach's alpha coefficient was .91, which is adequate for a group-based comparison (Nunnally \& Bernstein, 1994). The bivariate correlations between the predictor and output variables are presented in Table 2 .

Table 2. Bivariate correlations for predictors and output measures

\begin{tabular}{lllll}
\hline Measure & PE & EE & SF & FC \\
\hline EE & $.818^{* *}$ & & & \\
SF & $.699^{* *}$ & $.728^{* *}$ & & \\
FC & $.791^{* *}$ & $.810^{* *}$ & $.793^{* *}$ & $.822^{* *}$ \\
IU & $.783^{* *}$ & $.799^{* *}$ & $.709^{* *}$ &. \\
\hline
\end{tabular}

${ }^{*} p<.05, * * p<.01$.

The output measure correlated with all predictor variables. This result appears to provide initial validation for the UTAUT model in this socio-educational context. However, predictor variables appear intercorrelated, raising the possibility of multicollinearity. A value of 10 is considered the acceptable threshold for VIF values (Hair, Anderson, Tatham, \& Black, 1992; Kennedy, 1992; Marquardt, 1970; Neter, Wasserman, \& Kutner, 1989; O’Brien, 2007); thus, the observed figures appear acceptable. Although debate still exists concerning the acceptance threshold values for tolerance (e.g., Menard, 1995; Tabachnick \& Fidell, 2001), the tolerance observed met all suggested thresholds. Taken together, these figures indicate that multicollinearity lies within acceptable levels (see Table 3).

Table 3. Multicollinearity measures for predictors

\begin{tabular}{lll}
\hline Measure & Tolerance & Variance Inflation Factor \\
\hline PE & .389 & 2.568 \\
EE & .337 & 2.970 \\
SF & .347 & 2.878 \\
FC & .304 & 3.280 \\
\hline
\end{tabular}

Therefore, a simultaneous multiple regression analysis was undertaken to query the extent to which input variables predicted the behavioral intention to use iPads in English language learning at a technical, vocational college in Saudi Arabia. The predictors were performance expectancy, effort expectancy, social factors, and facilitating conditions. The output criterion was the behavioral intention to use iPads to learn English. The results are presented in Table 4 . Three of the four predictors account for $74 \%$ of the variance in the intention to use iPads to learn English, $F(4,193)=139.32, p<.01, R^{2}=.74$. The confidence intervals for these predictors did not include zero, providing further confirmation that these input variables are statistically significant predictors of the intention to use iPads to learn English as a second language. The effect size for this analysis $\left(f^{2}=2.85\right)$ exceeded Cohen's (1988) convention for a large effect $\left(f^{2}=.35\right)$. This indicates that those learners with a greater belief that the iPad will enhance learning, the device will be straightforward to use, and resources and support are available to support usage also tended toward a greater intention to maximize the use of iPads to support English learning.

Table 4. Regression analysis for variables predicting IU

\begin{tabular}{lllll}
\hline Variable & $B$ & $S E B$ & $\beta$ & CI \\
\hline PE & .212 & .066 & $.220^{* *}$ & $.081, .343$ \\
EE & .263 & .073 & $.261^{* *}$ & $.118, .408$ \\
SF & .057 & .071 & .050 & $-.083, .196$ \\
FC & .445 & .084 & $.398^{* *}$ & $.278, .611$ \\
\hline
\end{tabular}

$* p<.05, * * p<.01$. 
With the exception of social factors, all bivariate correlations between predictors and the intention to use iPads to learn English were significant. Table 5 presents indices that highlight the relative weight of individual predictors.

Table 5. Bivariate and partial correlations of predictors with IU

\begin{tabular}{lll}
\hline Predictors & $\begin{array}{l}\text { Correlations Between } \\
\text { Predictor and IU }\end{array}$ & $\begin{array}{c}\text { Each } \\
\text { Correlations Between Each } \\
\text { Predictor and IU Controlling for all } \\
\text { Other Predictors }\end{array}$ \\
\hline PE & $.78^{* *}$ & $.224^{* *}$ \\
$\mathrm{EE}$ & $.80^{* *}$ & $.250^{* *}$ \\
$\mathrm{SF}$ & .71 & .057 \\
$\mathrm{FC}$ & $.82^{* *}$ & $.355^{* *}$ \\
\hline
\end{tabular}

$* p<.05, * * p<.01$.

As demonstrated in Table 5, performance expectancy, effort expectancy, and facilitating conditions had significant $(p<0.01)$ zero-order correlations with the intention to use iPads. Only these same predictors had significant $(p<$ $0.01)$ partial effects in the full model.

\section{Discussion}

\section{$4.1 \mathrm{H1}$ - Performance Expectancy Will Have a Positive Influence on the Behavioral Intention to Use iPads}

Performance expectancy was demonstrated to be a valid predictor of the behavioral intention to use iPads, which is consistent with numerous prior studies (Al Gahtani et al., 2007; Boubert et al., 2015; Deng et al., 2011; Nassuora, 2013; Taiwo \& Downe, 2013). However, this result contrasts with other findings (Magsamen-Conrad et al., 2015; Sumak, Polancic, \& Hericko, 2010). Since beliefs about a given technology are often cited as a barrier to integration in an educational context (Ertmer, 1999, 2012), this study highlights the importance of both identifying and managing the beliefs held by users regarding the iPad as a language-learning tool. How to do so is the following question. Ertmer and Ottenbreit-Leftwich (2010) argued that, from an educator's perspective, providing evidence of successful student learning and ensuring the availability of support staff to ensure a beneficial initial experience with technology supports the development of positive values. Demonstrating success and providing prompt support should be equally encouraging from a learner's perspective and should be made a priority. This finding supports the UTAUT as a valid predictor of iPad acceptance in this context.

\subsection{H2 - Effort Expectancy Will Have a Positive Influence on the Behavioral Intention to Use iPads}

Effort expectancy was shown to be a significant predictor of acceptance of iPads. This finding is consistent with the findings of Deng et al. (2011), Magsamen-Conrad et al. (2015), and Nassuora (2013), although it conflicts with the findings of others (Al Ghatani \& Hubona, 2007; Boubert et al., 2015). Because lack of confidence is often cited as a barrier to integration of technology in educational contexts (Ertmer, 1999), educators and policymakers should ensure that the pacing and levels of scaffolding are carefully managed in order to maintain confidence among users who may be unfamiliar with not only the technology, but also the socio-constructivist approaches that complement a mobile learning approach. Again, the use of the UTAUT model as a measure of iPad acceptance is supported.

\subsection{H3 - Social Factors Will Have a Positive Influence on the Behavioral Intention to Use iPads}

Social factors were not observed to be a significant predictor of the intention to use iPads. This finding aligns with the results presented by Deng et al. (2011) and Magsamen-Conrad et al. (2015), yet it differs from the findings documented by Al Gahtani et al., (2007) and Maldonado et al. (2011). This result may be explained by the institutional context. At a technical vocational college, learners are effectively enrolled in a training course, overseen in part by their future employer. This may create a learning environment distinct from the greater freedom associated with conventional tertiary education. Thus, the demands of company policy may take precedence over the opinions of others.

\subsection{H4 - Facilitating Conditions Will Have a Positive Influence on the Behavioral Intention to Use iPads}

The findings indicate that facilitating conditions are a strong predictor of the intention to use iPads. This supports earlier work by Magsamen-Conrad et al. (2015) and Nassuora (2013). However, this finding contradicts the research undertaken by Al Ghatani et al. (2007) and Boubert et al. (2015). It is logical to presuppose that a lack of hardware, software access, training, and timely technical support could serve to hinder integration; indeed, this 
supposition has been well researched (Ertmer, 1999, 2005). Thus, IT support staff and policymakers must ensure that this supportive infrastructure is in place. This finding once more provides validation of the UTAUT as a measure of iPad acceptance.

The most important factor in determining acceptance of iPad devices was adequate facilitating conditions. This predictor was more pertinent among learners than the device's ease of use, which was marginally more important than beliefs that the iPad effectively supports L2 language learning. Institutions must, therefore, consider methods to identify the needs of learners and provide timely support. For example, the institution in question established a student technical support team, with representatives within each class. This has added an extra layer of timely support for learners and, indeed, educators. Furthermore, initiatives such as this can add to a greater sense of ownership of the learning process among learners. Ease of use is viewed as more important than the belief in the educational potential of the iPad, which could reflect difficulty associated with change as learners move from traditional, teacher-focused EFL environments into an institutional context where the device and student-focused pedagogy represent a challenging novelty. Educators and policymakers should carefully consider both task-related and technological scaffolding and progression in order to foster acceptance of devices. As a belief that iPads will result in enhanced language learning remains a significant predictor of acceptance, educators must also attempt to identify the values possessed by learners. In order to support a positive shift in values over time, one must consider aspects inherent to the model itself: careful pacing and scaffolding, initial and ongoing training within a supportive institutional context, adequate hardware and network, access to apps conducive to a learner-centered approach to EFL, and proficient and attentive support.

In summary, performance expectancy, effort expectancy, and facilitating conditions were found to predict the behavioral intention to use iPads. This provides evidence, albeit partial, supporting the validity of the UTAUT model in predicting acceptance of iPads within this educational context.

\subsection{Implications for Future Study}

It is important to address the limitations of this study in order to provide a basis for future research. First, the specific institutional context precluded factors of the UTAUT model unrelated to the research design: age, gender, and voluntariness of use. The predicted growth of the technical and vocational sector suggests both opportunity and utility in highlighting the impact of these factors in future studies of EFL learning in a MALL context. Additionally, the moderate sample size precluded subdivision by language proficiency level, as the relatively small size of subgroups would impact the stability results. Thus, future studies might investigate the possibility that the factors affecting the acceptance of technology differ between proficiency levels in this educational context, and the studies might provide implications for training and instructional design.

Furthermore, as they progress, learners in vocational settings may expect to spend less time in the classroom and more time in a situated learning environment, where English is the medium of instruction. They, therefore, must contend with a shift from classroom-based ESP to a learning environment where a more content-based approach (Cammarata, Tedick, \& Osborn, 2016) is taken to learning and using English. Mobile learning facilitates immediate, situated learning (Martin \& Ertzberger, 2013). It would be useful to implement the UTAUT model to address acceptance of the iPad as a language-learning tool in this context. Indeed, such research is currently underway at SESP.

\section{Conclusion}

The need to support learners in developing the necessary skills and values to adapt to e-learning has never been greater in the KSA. Seen by policymakers as a potential solution to ineffective, teacher-focused approaches to EFL education, an ideological commitment to educational technology is at the vanguard of substantial investment in educational reform. As part of this initiative, the number of learners in tertiary education studying EFL at technical and vocational colleges will increase considerably. Although the iPad remains the mobile device of choice in education, and despite the costs of integrating such technology, the factors that govern optimal acceptance of these devices as language learning tools remain under researched. To address this problem, this study applied the UTAUT to investigate learner acceptance of these devices.

The results obtained provide valuable insight of direct relevance to educators, researchers, and administrators concerned with effective integration of mobile devices across educational contexts. In particular, the findings are immediately pertinent for EFL learning in the KSA. Of note, the most important predictor of iPad acceptance among learners in this context was adequate facilitating conditions, highlighting the importance of providing the knowledge, hardware, software, training, and support necessary in a timely fashion. Also significant, to a lesser degree, was the expectation among learners that the system would be straightforward to use. This finding is consistent with a generation of learners unfamiliar with both educational technology and the student-focused 
learning paradigms aligned with m-learning, highlighting the need for careful pacing and scaffolding. The third most important predictor was a perception that the iPad enhanced language learning, raising awareness of the need to carefully support learners as they adopt these values through support, training and evidence of the usefulness of the device. Social factors were not observed to impact acceptance of the device, possibly due to the heightened importance of company policy and subsequent reduction in choice, specific to the institutional context. This finding is contrary to the expectations of the UTAUT model and highlights the importance of further research to better understand what underlies acceptance of educational technology in this expanding tertiary context. Further, the results indicate significant, but not complete, validation of the UTAUT model to understand acceptance of iPads as language-learning tools among male EFL learners in a technical vocational context in the KSA. Building on these findings, further research could adopt a wider lens, investigating acceptance of mobile learning in the more situated, practical learning contexts outside of the classroom that typify many vocational training contexts.

\section{References}

Abu-Al-Aish, A., \& Love, S. (2013). Factors influencing students' acceptance of M-Learning: An investigation in higher education. The International Review of Research in Open and Distributed Learning, 14(5), 82-107. Retrieved from http://www.irrodl.org/index.php/irrodl/article/view/1631/2711

Ajzen, I. (1991). The theory of planned behavior. Organizational Behavior and Human Decision Processes, 50(2), 179-211. http://dx.doi.org/10.1016/0749-5978(91)90020-T

Al-Asmari, A. M., \& Rabb Khan, M. S. (2014). E-learning in Saudi Arabia: Past, present and future. Near and Middle Eastern Journal of Research in Education, 2. http://dx.doi.org/10.5339/nmejre.2014.2

Al-Gahtani, S. S., Hubona, G. S., \& Wang, J. (2007). Information technology (IT) in Saudi Arabia: Culture and the acceptance and use of IT. Information \& Management, 44(8), 681-691. http://dx.doi.org/10.1016/j.im.2007.09.002

Al-Khotani, S., (2014). Ten Colleges of Excellence. Saudi Gazette. Retrieved from http://www.saudigazette.com.sa/index.cfm?method=home.regcon\&contentid=20130614169787

Al-Qeisi, K., Dennis, C., Hegazy, A., \& Abbad, M. (2015). How viable is the UTAUT model in a non-western context? International Business Research, 8(2), 204. http://dx.doi.org/10.5539/ibr.v8n2p204

Alrabai, F. (2016). Factors underlying low achievement of Saudi EFL learners. International Journal of English Linguistics, 6(3), 21. http://dx.doi.org/10.5539/ijel.v6n3p21

Alrashidi, O., \& Phan, H. (2015). Education context and English teaching and learning in the Kingdom of Saudi Arabia: An overview. English Language Teaching, 8(5), 33. http://dx.doi.org/10.5539/elt.v8n5p33

Alresheed, S., Leask, M., \& Raiker, A. (2015). Integrating computer-assisted language learning in Saudi schools: A change model. Turkish Online Journal of Educational Technology-TOJET, 14(4), 69-77.

Attuquayefio, S., \& Addo, H. (2014). Review of studies with UTAUT as conceptual framework. European Scientific Journal, 10(8).

Bandura, A. (1986). Social foundations of thought and action: A social cognitive theory. Englewood Cliffs, NJ: Prentice-Hall.

Blackwell, C. K., Lauricella, A. R., Wartella, E., Robb, M., \& Schomburg, R. (2013). Adoption and use of technology in early education: The interplay of extrinsic barriers and teacher attitudes. Computers \& Education, 69, 310-319. http://dx.doi.org/10.1016/j.compedu.2013.07.024

Boubert, L., Clements, M., Delaitre, T., Purdue, M., \& Lewis J. (2015). Mobile Learning Project [PowerPoint slides]. Retrieved from https://www.heacademy.ac.uk/system/files/downloads/7.8_boubert-ipads_in _the_classroom-mobile_learning_project.pdf

Cammarata, L., Tedick, D. J., \& Osborn, T. A. (2016). Content-based instruction and curricular reforms: Issues and goals. In L. Cammarata (Ed.), Content-based foreign language teaching: Curriculum and pedagogy for developing advanced thinking and literacy skills (pp. 1-22). New York, NY: Routledge.

Cohen, J. (1988). Statistical power analysis for the behavioural sciences (2nd ed). Hillsdale, New Jersey: Lawrence Erlbaum.

Davis, F. D. (1989). Perceived usefulness, perceived ease of use, and user acceptance of information technology. MIS Quarterly, 319-340. http://dx.doi.org/10.2307/249008

Davis, F. D., Bagozzi, R. P., \& Warshaw, P. R. (1992). Extrinsic and intrinsic motivation to use computers in the 
workplace. Journal of Applied Social Psychology, 22(14), 1111-1132. http://dx.doi.org/10.1111/j.1559-1816.1992.tb00945.x

Dhir, A., \& Al-kahtani, M. (2013, July). My iPad: A new learning tool for classrooms. In International Conference on Human-Computer Interaction (pp. 28-32). Berlin: Springer. http://dx.doi.org/10.1007/978-3-642-39476-8_6

Dhir, A., \& Al-kahtani, M. (2013, June). My iPad: A New Learning Tool for Classrooms. In HCI International 2013-Posters' Extended Abstracts: International Conference, HCI International 2013, Las Vegas, NV, USA, July 21-26, 2013, Proceedings (Vol. 374, p. 28). Springer.

Deng, S., Liu, Y., \& Qi, Y. (2011). An empirical study on determinants of web based question-answer services adoption. Online Information Review, 35(5), 789-798. http://dx.doi.org/10.1108/14684521111176507

Ertmer, P. A. (1999). Addressing first- and second-order barriers to change: Strategies for technology integration. Educational Technology Research and Development, 47(4), 47-61. http://dx.doi.org/10.1007/BF02299597

Ertmer, P. A. (2005). Teacher pedagogical beliefs: The final frontier in our quest for technology integration? Educational Technology Research and Development, 53(4), 25-39. http://dx.doi.org/10.1007/BF02504683

Ertmer, P. A., \& Ottenbreit-Leftwich, A. T. (2010). Teacher technology change: How knowledge, confidence, beliefs, and culture intersect. Journal of Research on Technology in Education, 42(3), 255-284. http://dx.doi .org/10.1080/15391523.2010.10782551

Fishbein, M., \& Ajzen, 1. (1975). Belief, attitude, intention, and behavior: An introduction to theory and research. Reading, MA: Addison Wesley.

Gasparini, A., \& Culen, A. (2011). IPad: a new classroom technology? A report from two pilot studies. Information Sciences and e-Society, 199-208. Retrieved from https://www.researchgate.net/publication/261611023_iPad_a_new_classroom_technology_A_report_from_t wo_pilot_studies

Hofstede, G. (1980). Culture's consequences: International differences in work-related values. Beverly Hills, CA: Sage Publications.

George, D., \& Mallery, M. (2010). SPSS for Windows step by step: A simple guide and reference, 17.0 update (10th Ed.). Boston: Pearson.

Gray, L., Thomas, N., \& Lewis, L. (2010). Teachers' Use of Educational Technology in US Public Schools: 2009. First Look. [NCES Report 2010-040]. Retrieved from https://nces .ed.gov/pubs2010/2010040.pdf

Hair, J. F., Anderson, R. E., Tatham, R. L., \& Black, W. C. (1992). Multivariate data analysis. New York: Macmillan.

Hew, K. F., \& Brush, T. (2007). Integrating technology into K-12 teaching and learning: Current knowledge gaps and recommendations for future research. Educational Technology Research and Development, 55(3), 223-252. http://dx.doi.org/10.1007/s11423-006-9022-5

Johnson, L. F., Smith, R. S., Smythe, J. T., \& Varon, R. K. (2009). Challenge-based learning: An approach for our time. Austin, Texas: New Media Consortium.

Kearney, M., Schuck, S., Burden, K., \& Aubusson, P. (2012). Viewing mobile learning from a pedagogical perspective. Research in Learning Technology, 20. http://dx.doi.org/10.3402/rlt.v20i0.14406

Kennedy, P. (1992). A guide to econometrics (3rd ed.). Oxford: Blackwell.

Liu, S. (2013). Teacher professional development for technology integration in a primary school learning community. Technology, Pedagogy and Education, 22(1), 37-54. http://dx.doi.org/10.1080/1475939X.2012 .719398

Magsamen-Conrad, K., Upadhyaya, S., Joa, C. Y., \& Dowd, J. (2015). Bridging the divide: Using UTAUT to predict multigenerational tablet adoption practices. Computers in Human Behavior, 50, $186-196$. http://dx .doi.org/10.1016/j.chb.2015.03.032

Maldonado, P., U., Feroz Khan, G., Moon, J., \& Rho, J. (2011). E-learning motivation and educational portal acceptance in developing countries. Online Information Review, 35(1), 66-85. http://dx.doi.org/10.1108/14684521111113597

Marquardt, D. W. (1970). Generalized inverses, ridge regression, biased linear estimation, and nonlinear 
estimation. Technometrics, 12(3), 591-612. http://dx.doi.org/10.1080/00401706.1970.10488699

Martin, F., \& Ertzberger, J. (2013). Here and now mobile learning: An experimental study on the use of mobile technology. Computers \& Education, 68, 76-85. http://dx.doi.org/10.1016/j.compedu.2013.04.021

Menard, S. (1995). Applied logistic regression analysis: Sage university series on quantitative applications in the social sciences. Thousand Oaks, CA: Sage

Murray, O. T., \& Olcese, N. R. (2011). Teaching and learning with iPads, ready or not? TechTrends, 55(6), 42-48. http://dx.doi.org.ezproxy.rit.edu/10.1007/s11528-011-0540-6

Nassuora, A. B. (2013). Students' acceptance of mobile learning for higher education in Saudi Arabia. International Journal of Learning Management Systems, 1(1), 1. http://dx.doi.org/10.12785/ijlms/010101

Neter, J., Wasserman, W., \& Kutner, M. H. (1989). Applied regression models. Homewood, IL: Irwin.

Nunnally, J. C., \& Bernstein, I. H. (1994). Psychometric theory. New York: McGraw-Hill.

O'Brien, R. M. (2007). A caution regarding rules of thumb for variance inflation factors. Quality \& Quantity, 41(5), 673-690. http://dx.doi.org/10.1007/s11135-006-9018-6

O'Mahony, C. (2003). Getting the information and communications technology formula right: access + ability= confident use. Technology, Pedagogy and Education, 12(2), 295-311. http://dx.doi.org/10.1080/14759390300200159

Rajab, H. (2013). Developing speaking and writing skills of L1 Arabic EFL learners through teaching of IPA phonetic codes. Theory and Practice in Language Studies, 3(4), 653. http://dx.doi.org/10.4304/tpls.3.4.653-659

Rogers, E. M. (1995). Diffusion of Innovation. New York, NY: Free Press.

Stockwell, G. (2013). Technology and motivation in English-language teaching and learning. In International perspectives on motivation (pp. 156-175). UK: Palgrave Macmillan.

Šumak, B., Polancic, G., \& Hericko, M. (2010, February). An empirical study of virtual learning environment adoption using UTAUT. Paper presented at the Second International Conference on Mobile, Hybrid and Online Learning Conference Proceedings. http://dx.doi.org/10.1109/eLmL.2010.11

Tabachnick, B. G., \& Fidell, L. S. (2001). Using Multivariate Statistics (4th ed). Boston, MA: Allyn \& Bacon

Taiwo, A. A., \& Downe, A. G. (2013). The theory of user acceptance and use of technology (UTAUT): A meta-analytic review of empirical findings. Journal of Theoretical \& Applied Information Technology, 49(1), 48-58.

Taylor, S., \& Todd, P. (1995). Assessing IT usage: The role of prior experience. MIS Quarterly, 19(4), 561-570. http://dx.doi.org/10.2307/249633

Thompson, R. L., Higgins, C. A., \& Howell, J. M. (1991). Personal computing: Toward a conceptual model of utilization. MIS Quarterly, 15(1), 125-143. http://dx.doi.org/10.2307/249443

Venkatesh, V., \& Davis, F. D. (2000). A theoretical extension of the technology acceptance model: Four $\begin{array}{lllll}\text { longitudinal field } & \text { studies. }\end{array}$ http://dx.doi.org/10.1287/mnsc.46.2.186.11926

Venkatesh, V., Morris, M. G., Davis, G. B., \& Davis, F. D. (2003). User acceptance of information technology: Toward a unified view. MIS Quarterly, 27(3), 425-478. Retrieved from http://www.jstor.org/stable/30036540 


\section{Appendix}

Learner Survey

Please share your thoughts on the recent introduction of iPads at SESP. If you agree to participate in the survey, please answer the questions honestly. This survey is confidential.

Instructions:

Please check one box for each question to show how much you agree or disagree with the statement.

\begin{tabular}{|l|l|l|l|l|l|}
\hline The iPad as a tool for learning English & Agree & $\begin{array}{l}\text { Neither } \\
\text { Agree nor } \\
\text { Disagree }\end{array}$ & $\begin{array}{l}\text { Disagree } \\
\text { Statement }\end{array}$ & $\begin{array}{l}\text { Strongly } \\
\text { Disagree }\end{array}$ & \\
\hline $\begin{array}{l}\text { 1. I find the iPads useful to my studies in the } \\
\text { classroom. }\end{array}$ & & & & & \\
\hline $\begin{array}{l}\text { 2. Using the iPads increases my } \\
\text { productivity. }\end{array}$ & & & & & \\
\hline $\begin{array}{l}\text { 3. Using the iPads increases my chances of } \\
\text { getting good grades. }\end{array}$ & & & & & \\
\hline $\begin{array}{l}\text { 4. I find the iPads useful to my studies at } \\
\text { home. }\end{array}$ & & & & \\
\hline
\end{tabular}

\begin{tabular}{|c|c|c|c|c|c|}
\hline \multicolumn{6}{|c|}{ How easy it is to use the iPad when learning English } \\
\hline Statement & $\begin{array}{l}\text { Strongly } \\
\text { Agree }\end{array}$ & Agree & $\begin{array}{l}\text { Neither } \\
\text { Agree nor } \\
\text { Disagree }\end{array}$ & Disagree & $\begin{array}{l}\text { Strongly } \\
\text { Disagree }\end{array}$ \\
\hline \multicolumn{6}{|l|}{$\begin{array}{l}\text { 5. This section asks about how easy or } \\
\text { difficult it is to use the iPad. }\end{array}$} \\
\hline \multicolumn{6}{|l|}{$\begin{array}{l}\text { 6. I find the iPad clear and understandable } \\
\text { to use. }\end{array}$} \\
\hline \multicolumn{6}{|l|}{$\begin{array}{l}\text { 7. It is easy for me to become skilful at } \\
\text { using the iPad. }\end{array}$} \\
\hline \multicolumn{6}{|l|}{$\begin{array}{l}\text { 8. I find it easy to use the iPad in the } \\
\text { classroom. }\end{array}$} \\
\hline $\begin{array}{l}\text { 9. I find it easy to use the iPad to study at } \\
\text { home. }\end{array}$ & & & & & \\
\hline
\end{tabular}

\begin{tabular}{|l|l|l|l|l|l|}
\hline \multicolumn{2}{|l|}{ What other people think about using the iPad to learn English } & $\begin{array}{l}\text { Agree } \\
\text { Agree } \\
\text { Statement }\end{array}$ & $\begin{array}{l}\text { Agree nor } \\
\text { Disagree }\end{array}$ & $\begin{array}{l}\text { Disagree } \\
\text { Strongly } \\
\text { Disagree }\end{array}$ \\
$\begin{array}{l}\text { 10. This section asks about what other } \\
\text { people think about using iPads. }\end{array}$ & & & & & \\
\hline $\begin{array}{l}\text { 11. Instructors at my institute have assisted } \\
\text { me in using the iPad. }\end{array}$ & & & & & \\
\hline $\begin{array}{l}\text { 12. Administrators at my institution have } \\
\text { been helpful in the use of the iPad. }\end{array}$ & & & & & \\
\hline \begin{tabular}{l} 
13. My classmates think we should use the \\
\hline
\end{tabular}
\end{tabular}


iPad to study and learn.

What I need to use the iPad when learning English

\begin{tabular}{|c|c|c|c|c|c|}
\hline Statement & $\begin{array}{l}\text { Strongly } \\
\text { Agree }\end{array}$ & Agree & $\begin{array}{l}\text { Neither } \\
\text { Agree nor } \\
\text { Disagree }\end{array}$ & Disagree & $\begin{array}{l}\text { Strongly } \\
\text { Disagree }\end{array}$ \\
\hline $\begin{array}{l}\text { 14. I have the knowledge I need to use the } \\
\text { iPad well. }\end{array}$ & & & & & \\
\hline $\begin{array}{l}\text { 15. A specific person (or group) is available } \\
\text { to help me with technical difficulties. }\end{array}$ & & & & & \\
\hline $\begin{array}{l}\text { 16. I have all the software resources (for } \\
\text { example, apps) necessary to use the iPad. }\end{array}$ & & & & & \\
\hline 17. I have access to adequate hardware. & & & & & \\
\hline
\end{tabular}

My intentions to use the iPad when learning English

\begin{tabular}{|l|l|l|l|l|l|}
\hline Statement & $\begin{array}{l}\text { Strongly } \\
\text { Agree }\end{array}$ & Agree & $\begin{array}{l}\text { Neither } \\
\text { Agree nor } \\
\text { Disagree }\end{array}$ & $\begin{array}{l}\text { Disagree } \\
\text { Strongly } \\
\text { Disagree } \\
\text { over intend to use the iPad when possible }\end{array}$ & \\
\hline $\begin{array}{l}\text { 19. I predict that I will use the iPad to learn } \\
\text { when I have the chance to do so in the } \\
\text { future. }\end{array}$ & & & & & \\
\hline $\begin{array}{l}\text { 20. I plan to use the iPad to learn English } \\
\text { whenever I can. }\end{array}$ & & & & & \\
\hline
\end{tabular}

\section{Copyrights}

Copyright for this article is retained by the author(s), with first publication rights granted to the journal.

This is an open-access article distributed under the terms and conditions of the Creative Commons Attribution license (http://creativecommons.org/licenses/by/4.0/). 